\title{
KAJIAN TINKGAT PENGANGGURAN TERBUKA PEREMPUAN DI KOTA MANADO
}

\author{
Sutomo Wim Palar, Een N. Walewangko. Albert T. Londa \\ Fakultas Ekonomi dan Bisnis, Ekonomi Pembangunan \\ Universitas Sam Ratulangi, Manado
}

\begin{abstract}
ABSTRAK
Masalah pengangguran merupakan salah satu masalah utama makro ekonomi yang menjadi penghambat pembangunan daerah karena akan meninmbulkan masalah-masalah sosial lainnya. Daya serap pasar kerja selain terbatas yang menyebabkan banyaknya angkatan kerja yang menganggur ternyata masalah permintaan tenaga kerja dengan tingkat keahlian khusus membuat tenaga kerja yang ada tidak terserap oleh pasar kerja. Jika tingkat pengangguran di suatu negara relatif tinggi, hal tersebut akan menghambat pencapaian tujuan pembangunan ekonomi yang telah dicita-citakan.Penelitian ini bertujuan untuk mengidentifikasi karakteristik pengangguran perempuan, faktor-faktor dominan yang menyebabkan pengangguran yang ada di Kota Manado, dan menganalisis sektor potensial yang menyerap tenaga kerja perempuan sesuai dengan kualifikasi pencari kerja perempuan yang ditersedia.Pengangguran adalah seseorang yang sudah digolongkan dalam angkatan kerja yang sedang aktif mencari pekerjaan pada suatu tingkat upah tertentu tetapi tidak dapat memperoleh pekerjaan yang diinginkannya. Data yang di gunakan adalah sekunder yaitu data Sakernas dan Sakerda Tahun 2012. Serta data primer yang diperoleh dari informasi rumahtangga, perusahaan dan kegiatan pemerintah daerah berhubungan dengan aktivitas perempuan di Kota Manado. Metode yang digunakan adalah metode deskriptif untuk menghasilkan identifikasi berbagai karakteristik pencari kerja perempuan. Dan metode inferensia untuk melihat pola perilaku dan hubungan-hubungan antar variabel yang diduga menjadi faktor yang signifikan mempengaruhi pengangguran perempuan di Kota Manado.
\end{abstract}

\section{Kata Kunci : Ketenagakerjaan, Pengangguran}

\begin{abstract}
The problem of unemployment is one of the major macroeconomic problems that become an obstacle for regional development will meninmbulkan other social problems. Labor market absorption in addition to the limited labor force which caused the number of unemployed turned out the problem of labor demand with a specific skill level to make the existing workforce is not absorbed by the labor market. If the unemployment rate is relatively high in a country, it would hinder the achievement of economic development goals that have aspired. This study aims to identify the characteristics of female unemployment, the dominant factors that cause unemployment in the city of Manado, and analyze the potential sectors that absorb women's employment in accordance with the qualifications of women job seekers are often insufficient.Unemployment is someone who has been classified in the workforce who are actively looking for a job at a certain wage level but can not get a job he wanted. Data used was secondary that Sakernas and Sakerda 2012. As well as primary data obtained from the information of households, enterprises and regional activities related to the activities of women in the city of Manado. The method used is descriptive method for the identification of various characteristics of female job seekers. And methods of inference to see patterns of behavior and relationships between variables thought to be a significant factor affecting the female unemployment in the city of Manado.
\end{abstract}

Keywords: Employment, Unemployment 


\section{Pendahuluan}

Salah satu masalah utama makro ekonomi yang menjadi penghambat pembangunan daerah adalah masalah pengangguran. Daya serap pasar kerja selain terbatas yang menyebabkan banyaknya angkatan kerja yang menganggur ternyata masalah permintaan tenaga kerja dengan tingkat keahlian khusus membuat tenaga kerja yang ada tidak terserap oleh pasar kerja. Jika tingkat pengangguran di suatu negara relatif tinggi, hal tersebut akan menghambat pencapaian tujuan pembangunan ekonomi yang telah dicita-citakan.

Fenomena pengangguran dilihat dari sisi suplly dan demand atau pasar kerja bersifat kompleks. Pada dasarnya pengangguran terjadi disebabkan oleh banyak faktor. Penyebab utamanaya adalah karena kapasitas atau kemampuan dan ketrampilan si pencari kerja rendah dan tidak sesuai dengan kriteria yang diinginkan oleh pasar tenaga kerja. Di samping itu, banyaknya tenaga pengangguran usia produktif yang berkapasitas rendah, membuat pasar tidak mau menyerapnya. Orientasi para pencari kerja hanya pada sektor-sektor jasa yang diarasakan mudah saja. Sehingga ketika tingkat persaingan yang tinggi, dianggap bahwa pasar tenaga kerja tidak mampu menyerap tenaga kerja yang ada .Akibatnya timbul sejumlah pekerja yang tidak diberdayakan dalam kegiatan perekonomian. Ini semua akibat penawaran tenaga kerja di pasar tenaga kerja melebihi pemintaan tenaga kerja untuk mengisi kesempatan kerja yang tersedia.

Tabel 1.1. Kondisi Makro Ekonomi Kota Manado Tahun 2011 - 2014

\begin{tabular}{|l|c|c|c|c|c|}
\hline \multicolumn{1}{|c|}{ Uraian } & Satuan & $\mathbf{2 0 1 1}$ & $\mathbf{2 0 1 2}$ & $\mathbf{2 0 1 3}$ & $\mathbf{2 0 1 4}$ \\
\hline $\begin{array}{l}\text { Pertumbuhan } \\
\text { Ekonomi }\end{array}$ & $\%$ & 7,80 & 7,11 & 7,22 & 6,48 \\
\hline PDRB per Kapita & $\mathrm{Rp}$ & $38,19 \mathrm{jt}$ & $42,50 \mathrm{jt}$ & $47,36 \mathrm{jt}$ & $53,03 \mathrm{jt}$ \\
\hline Inflasi & $\%$ & 0,67 & 6,04 & 8,12 & 9,67 \\
\hline Pengangguran & $\%$ & 11,48 & 10,85 & 8,78 & 9,59 \\
\hline Kemiskinan & $\%$ & 5,40 & 4,91 & 4,88 & 4,74 \\
\hline
\end{tabular}

Sumber : Bappeda Kota Manado, 2016

Tabel 1.1. menunjukkan bahwa dalam perlambatan pertumbuhan ekonomi di Kota Manado (tahun 2015 sebesar 6,48 \%), PDRB Perkapita tetap meningkat menjadi 53,03 juta rupiah per tahun, inflasi meningkat menjadi 9,67 \% dan angka kemiskinan turun menjadi 4,74 \%. Fenomena pengangguran mengalami peningkatan menjadi 9,59 \% yang berbanding terbalik dengan kemiskinan. Hal ini penting menjadi perhatian pemerintah Kota Manado.

Tingkat pengangguran perempuan dari tahun ke tahun selalu lebih tinggi dari pada tingkat pengangguran laki-laki. Fenomena tingginya pencari kerja perempuan di Kota Manado yang menjadi ibukota Provinsi Sulawesi Utara menjadi target unit analisa dalam penelitian ini. Penelitian ini diharapkan akan mampu mengidentifikasi faktor penyebab dominan pengangguran wanita serta karakteristik pencari kerja perempuan yang ada di Kota Manado. Pengangguran yang berkepanjangan juga dapat menimbulkan efek psikologis yang buruk terhadap penganggur dan keluarganya. 
Secara khusus tujuan dari penelitian ini adalah :

a. Untuk mengidentifikasi karakteristik pengangguran perempuan yang ada di Kota Manado.

b. Untuk mengidentifikasi faktor-faktor dominan yang menyebabkan mereka menganggur.

c. Untuk menganalisis sektor yang potensial menyerap tenaga kerja perempuan sesuai dengan kualifikasi pencari kerja perempuan yang ditersedia.

\section{KETENAGAKERJAAN}

Pengertian tenaga kerja yang dimuat dalam Undang-Undang Pokok Ketenagakerjaan No. 13 Tahun 2003 tentang Ketenagakerjaan adalah : (1) segala hal yang berhubungan dengan tenaga kerja pada waktu sebelum, selama dan sesudah masa kerja; (2) setiap orang yang mampu melakukan pekerjaan guna menghasilkan barang dan jasa untuk memenuhi kebutuhan sendiri maupun kebutuhan masyarakat.

Menurut Rahardja dan Manurung (2000) mendefinisikan kesempatan kerja adalah banyaknya lapangan pekerjaan yang tersedia untuk angkatan kerja. Muana Nanga (2005), mendefinisikan penggangguran sebagai suatu keadaan dimana seseorang yang tergolong dalam kategori angkatan kerja tidak memiliki pekerjaan dan secara aktif sedang mencari pekerjaan. Dilihat dari sebab-sebab timbulnya, pengangguran dapat dibedakan atas : Pengangguran friksional, Pengangguran struktural, Pengangguran alamiah, dan Pengangguran siklis atau konjungtural.

Menurut BPS pengangguran terbuka adalah penduduk usia kerja yang selama seminggu yang lalu tidak melakukan kegiatan bekerja dan sedang mencari pekerjaan, mempersiapkan suatu usaha, mereka yang tidak mungkin mendapatkan pekerjaan, dan sudah punya pekerjaan tetapi belum bekerja. Secara umum pengangguran dapat digolongkan atas 3 (tiga ) bagian besar yaitu : Pengangguran Terselubung (Disguissed Unemployment), Setengah Menganggur (Under Unemployment), dan Pengangguran Terbuka (Open Unemployment).

\section{HASIL PENELITIAN TERDAHULU}

Penelitian Galbraith \& Garcilazo (2004) tentang “ Unemployment, Inequality and The Policy of Europe: 1984-2000" menyatakan bahwa tingkat pengangguran berhubungan positif dengan besarnya suatu daerah. Dalam suatu perekonomian yang terintegrasi memiliki karakteristik daerah dengan tingkat karakteristik pengangguran tertentu. Pengangguran di Eropa cenderung berkonsentrasi karakteristik nasional dengan penyebab utama adalah 'kekakuan' pasar tenaga kerja.

Tahun 2012 Congress Budget Office (CBO) meneliti tentang “ Understanding and Responding to Persistently High Unemployment". Data menunjukkan bahwa tingkat pengangguran di Amerika Serikat melebihi 8 persen sejak Februari 2009, angka ini cukup tinggi. CBO menganalis beberapa kebijakan yang bertujuan untuk meningkatkan perekonomian dan permintaan barang dan jasa. Kebijakan pelatihan pekerja ke sistem asuransi pengangguran (Unemployment Insurance), dan membantu transisi penganggur yang menunggu pekerjaan baru 
ternyata tidak memiliki pengaruh yang signifikan terhadap tingkat pengangguran selang dua tahun ke depan.

Kajian tentang pengangguran juga dilakukan oleh Pravin Visaria (1998) di India dengan topik "Unemployment among youth in India: Level, nature and policy implications". Pemuda telah diakui sebagai "yang paling penting sebagian masyarakat di India sehingga diantara permasalahan yang dihadapi oleh pemuda masalah pengangguran kaum muda menjadi prioritas.

John C Ham dkk meneliti khusus pengangguran perempuan di Ceko dengan topik "Women Unemployment During The Transition : Evidence From Czech and Slovak Micro Data". Mereka menganalisis probabilitas mingguan wanita meninggalkan pengangguran atau mulai bekerja di Ceko dan Slowakia Republics (CR dan SR). Hasil penelitian menunjukkan bahwa terdapat perbedaan dalam perilaku, pengusaha individu dan lembaga di SR dan CR. Terdapat pengaruh variabel demografis, perbedaan penentu probabilitas perempuan cepat bekerja di Republik Ceko (CR) daripada di Republik Slovakia (SR).

Sahin, Song dan Hobijn (2009), lewat "The Unemployment Gender Gap During The 2007 Recession", yang intinya menemukan gap lebih baik pada perempuan daripada pria setelah adanya resesi. Pada Agustus 2009, tingkat pengangguran untuk pria mencapai 11,0 persen, sedangkan untuk perempuan hanya 8,3 persen. Kajian tentang "Women in The Labour Market" menunjukkan bahwa resesi memiliki dampak yang signifikan terhadap prospek pasar tenaga kerja perempuan dan laki-laki di Inggris.

Penelitian ini disponsori oleh pemerintah India (2002) dengan judul "A Study of Unemployment Among Female Graduates In Pune City". Terdapat fenomena meluasnya pengangguran di kalangan lulusan wanita di Maharashtra. Tujuan dari penelitian ini adalah menganalisis dimensi utama dari produktivitas ekonomi dari pendidikan dalam hubungannya dengan ilmu pengetahuan dan teknologi. Terdapat kelemahan pada sistem pendidikan liberal yang diadopsi atau diberikan 'Brahminical' status sosial di negara kita. Tugas produktivitas ekonomi menjadi tanggung jawab kelas sosial pengrajin. Oleh karena itu, sulit untuk menyelaraskan sistem pendidikan tinggi saat ini, dan terutama untuk pendidikan perempuan. Peran perempuan sebagai ibu rumah tangga dan produsen sehingga pilihan pekerjaan menjadi kendala utama. Faktor budaya dan tradisi keluarga menyatakan keibuan dianggap sebagai tugas yang merupakan panggilan dari perempuan.

\section{METODE PENELITIAN}

Data yang di gunakan adalah sekunder yaitu data Sakernas dan Sakerda Tahun 2015 yang bersumber dari Badan Pusat Statistik dan Bappeda Provinsi Sulawesi Utara. Data survey by name by address yang dikeluatkan oleh TNP2K dan telah diverifikasi oleh Kementrian Sosial Tahun 2015. Serta dilengkapi dengan informasi tambahan dari lapangan yang berupa data primer berupa interview mendalam yang diperoleh dari rumahtangga, perusahaan dan instansi terkait dengan penelitian ini yaitu Bappeda Kota Manado dan Dinas Tenaga Kerja Kota Manado. 
Metode analisis deskriptif yang memberikan gambaran untuk mengidentifikasi karakteristik tenaga kerja perempuan yang ada di Kota Manado. Terdapat metode analisis ekonometrika digunakan untuk mengukur berapa besar pengaruh faktor-faktor yang menyebabkan pengangguran perempuan di Kota Manado. Juga melihat peran sektor yang menyerap tenaga kerja perempuan di Kota Manado.

\section{HASIL PENELITIAN}

TPAK Kota Manado terus berfluktuasi selama lima tahun terakhir namun pada dua tahun terakhir TPAK Kota Manado ada di bawah rata-rata Provinsi Sulawesi Utara, dimana TPAK Kota Manado 2013 (60\%) Sulut (66,14\%); Manado 2013 (60,01\%) Sulut (59,99\%). Dari data yang ada, terlihat bahwa tingkat partisipasi angkatan kerja di Kota Manado dari tahun 2012 sampai tahun 2014 terjadi penurunan yaitu dari prosentase 63,20\% pada tahun 2012 turun sebesar $6 \%$ menjadi 56,21\%. Kondisi ini juga sejalan dengan naiknya angka pengangguran di tahun 2014 menjadi $9,59 \%$ dari angka $8,7 \%$ di tahun sebelumnya.

Tabel 1. Penduduk Kota Manado Berumur 15 Tahun Keatas Menurut Jenis Kegiatan Utama di Kota Manado Tahun 2012 - 2014

\begin{tabular}{|l|c|c|c|}
\hline \multicolumn{1}{|c|}{ Uraian } & $\mathbf{2 0 1 2}$ & $\mathbf{2 0 1 3}$ & $\mathbf{2 0 1 4}$ \\
\hline Angkatan Kerja & 172,168 & 174,427 & 163,419 \\
\hline Bekerja & 20,947 & 16,791 & 17,344 \\
\hline Mencari Pekerjaan & 34,653 & 41,903 & 45,398 \\
\hline Bukan Angkatan Kerja & 61,618 & 68,068 & 68,332 \\
\hline Sekolah & 17,068 & 17,442 & 27,087 \\
\hline Mengurus RT & \multicolumn{3}{|l|}{} \\
\hline Lainnya & $\mathbf{3 1 8 , 6 3 1}$ & $\mathbf{3 2 1 , 5 8 0}$ \\
\hline Jumlah & $\mathbf{6 0 6 , 4 5 4}$ & $\mathbf{6 6 . 0 1 \%}$ & \\
\hline $\begin{array}{l}\text { Tingkat Partisipasi } \\
\text { Angkatan Kerja } \\
\text { (TPAK) }\end{array}$ & $\mathbf{6 3 . 2 0 \%}$ & $\mathbf{8 . 7 0 \%}$ & $\mathbf{9 . 6 0 \%}$ \\
\hline Tingkat Pengangguran & $\mathbf{1 0 . 8 0 \%}$ &
\end{tabular}

Sumber : BPS Kota Manado, 2016

Dari data yang ada terlihat bahwa di tahun 2014 terjadi penurunan total penduduk angkatan kerja dibandingkan dengan tahun 2013 dimana terjadi penurunan sebanyak 11,008 orang $(6,31 \%)$. 
Tabel 2. Penduduk Kota Manado Berumur 15 Tahun Keatas Menurut Jenis Kelamin dan Lapangan Pekerjaaan Utama Tahun 2014

\begin{tabular}{|l|c|c|c|c|}
\hline \multicolumn{1}{|c|}{ URAIAN } & $\begin{array}{c}\text { LAKI_LA } \\
\text { KI }\end{array}$ & $\begin{array}{c}\text { PEREMPU } \\
\text { AN }\end{array}$ & TOTAL & $\begin{array}{c}\text { TAHUN } \\
\mathbf{2 0 1 0}\end{array}$ \\
\hline $\begin{array}{l}\text { Pertanian, Perkebunan, } \\
\text { Kehutanan, Perburuan, dan } \\
\text { Perikanan }\end{array}$ & 5,218 & 765 & 5,983 & 9,509 \\
\hline Pertambangan dan Penggalian & - & - & - & 841 \\
\hline Industri & 5,362 & 1,930 & 7,292 & 8,063 \\
\hline Listrik Gas dan Air & - & - & - & 1,324 \\
\hline Konstruksi & 18,263 & & 18,263 & 15,901 \\
\hline $\begin{array}{l}\text { Perdagangan Rumah Makan \& } \\
\text { Jasa Akomodasi }\end{array}$ & 27,784 & 31,985 & 59,769 & 55,901 \\
\hline $\begin{array}{l}\text { Transportasi, Pergudangan, \& } \\
\text { Komunikasi }\end{array}$ & 18,559 & 1,615 & 20,174 & 25,082 \\
\hline $\begin{array}{l}\text { Keuangan, Real Estate, } \\
\text { Persewaan, \& Jasa Perusahaan }\end{array}$ & 7,837 & 2,084 & 9,921 & 7,475 \\
\hline $\begin{array}{l}\text { Jasa Kemasyarakatan, Sosial, \& } \\
\text { Perorangan }\end{array}$ & 24,975 & 22,045 & 47,020 & 55,973 \\
\hline Jumlah & 107,998 & 60,424 & 168,422 & 180,167 \\
\hline
\end{tabular}

Sumber : BPS Kota Manado, 2016

Penduduk Kota Manado bekerja di 9 (sembilan) jenis lapangan usaha seperti yang tampak padan tabel di bawah ini. Terlihat bahwa di tahun 2014, sektor perdagangan, rumah makan, dan jasa Akomodasi menyerap tenaga kerja terbanyak dengan 59,769 orang menggeser sektor Jasa Kemasyarakatan, Sosial, \& Perorangan yang berhasil menyerap tenaga kerja sebesar 55,973 orang di tahun 2010. Fenomena ini menunjukan bahwa ada pergereseran sector ekonomi ke arah sector tersier yang sebagai salah satu penyumbang terbesar PDRB di Kota Manado. Berbeda halnya dengan tenaga kerja sector Pertanian, perkebunan, kehutanan, perburuan, dan perikanan yang mengalami penurunan drastis sejak tahun 2010 dari semula mampu menyerap 9,509 orang, di tahun 2014 hanya mampu menyerap 5,983 atau berkurang hampir setengahnya. Hal ini sejalan dengan berkurangnya area lahan pertanian di Kota Manado, sebagai contoh lahan padi sawah sudah sama sekali tidak ada lagi. Tenaga kerja di sector pertambangan dan penggalian; Listrik, gas, dan air di tahun 2014 tidak lagi mampu menyerap tenaga kerja.

Berdasarkan tingkat kesejahteran keluarga menunjukkan bahwa rumahtangga pra sejahtera desil 1 sebanyak $3640 \mathrm{kk}$ terdapat 4,74 persen adalah penduduk miskin. Dilihat dari penyebarannya menurut kecamatan yang ada di Kota Manado terbesar berada di Kecamatan Paal Dua, diikuti Kecamatan Mapanget dan Singkil. 


\section{Gambar 1. Jumlah Rumah Tangga Pra Sejahtera dan Kepala Rumah Tangga Perempuan Menurut Kecamatan di Kota Manado Tahun 2015}

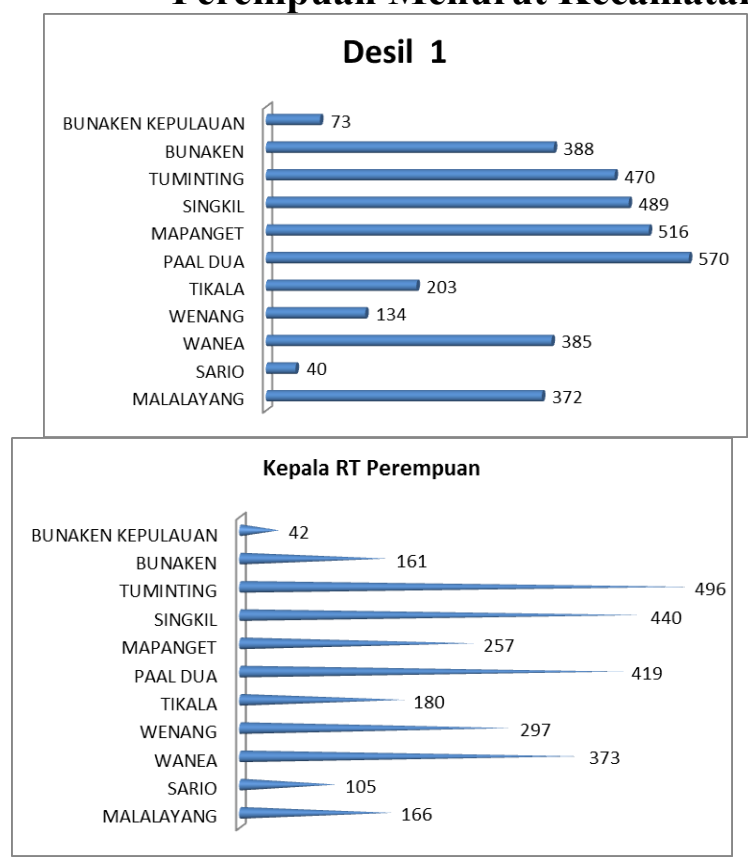

Sumber : BDT, Diolah 2016

Data survey menunjukkan dari 2936 kepala rumahtangga perempuan yang terdapat di Kota Manado, ternyata terbanyak di Kecamatan Tuminting dan Singkil. Peran perempuan di kedua kecamatan ini sangat berpengaruh bagi keberlangsungan hidup rumahtangga. Sedangkan Kecamatan Bunaken Kepulauan dan Sario memiliki kepala rumahtangga perempuan yang paling sedikit. Secara lebih rinci menunjukkan bahwa kepala rumahtangga perempuan terbanyak memiliki usia $>60$ tahun sebesar 44 persen. Ini berarti mereka menjadi kepala rumahtangga lebih disebabkan karena suaminya telah meninggal terlebih dahulu. Peran perempuan yang berada pada usia produktif mencapai 38 persen ini berarti tingkat produktivitas kepala rumahtangga harus terus dioptimalkan untuk meningkatkan pendapatan keluarga. 
Gambar 2. Jumlah APS Perempuan dan per Kecamatan di Kota Manado Tahun 2015

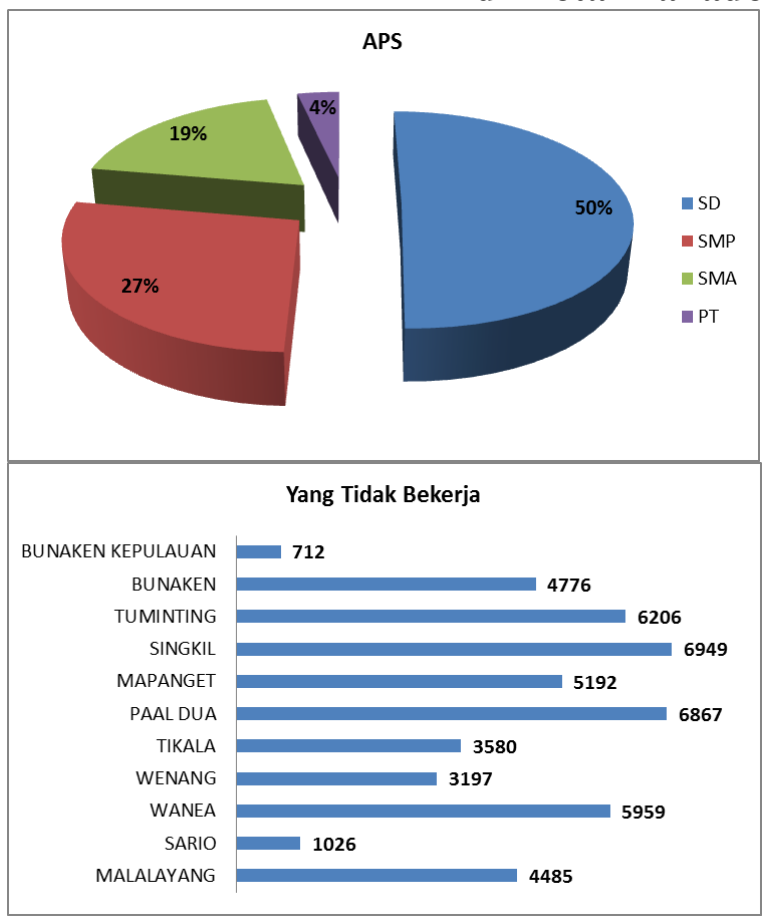

Sumber : BDT, Diolah 2016

Angka partisipasi anak perempuan untuk sekolah sebagai implementasi pengembangan pendidikan yang dimilikinya terbesar adalah tingkat SD yaitu sebesar 50 persen. Yang ingin lulus SMA hanya mencapai 19 persen diatas APS perguruan tinggi.

Kualitas anak-anak perempuan yang mau sekolah lanjut ke jenjang berikutnya masih sangat rendah. Pemerintah daerah harus memiliki program-program khusus untuk merangsang mereka lanjut ke jenjang yang lebih tinggi. Tingkat pendidikan mempengaruhi pekerjaan di masa yang akan datang.

Survey Basis Data Terpadu by name by address yang digunakan menunjukkan bahwa individu yang terdapat di Kota Manado yang tidak bekerja terbanyak di Kecamatan Sigkil dan Paal Dua. Namun secara terperinci dapat di lihat pada gambar berikut ini : 
Gambar 3. Jumlah Individu Usia Non Produktif Yang Bekerja Menurut Kecamatan di Kota Manado Tahun 2015

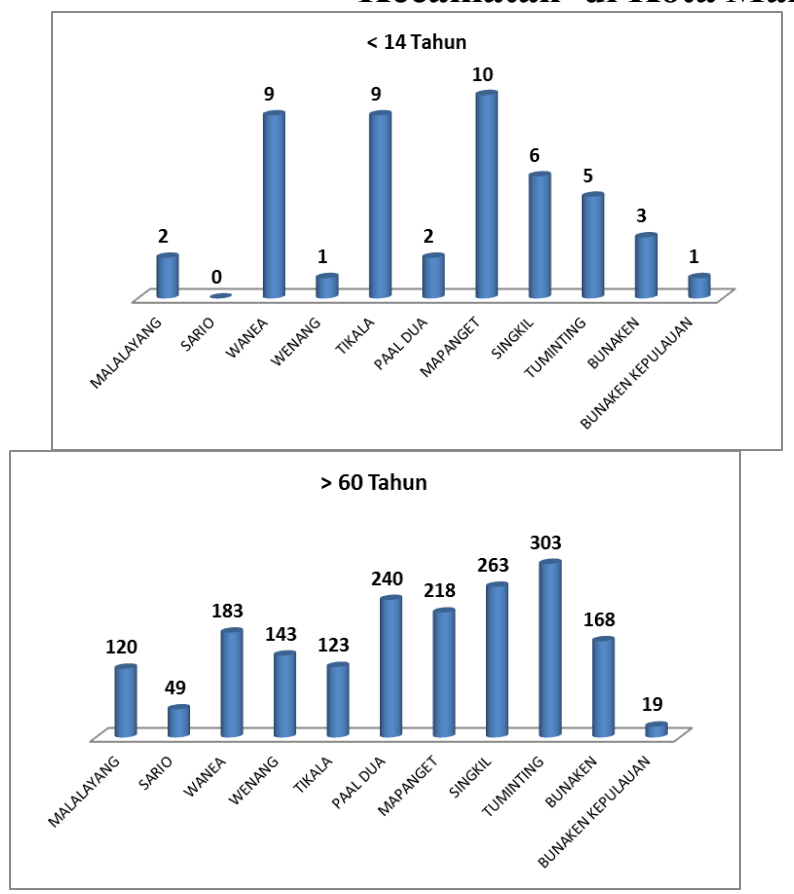

Sumber : BDT, Diolah 2016

Tampak bahwa terdapat anak yang belum cukup umur tapi sudah bekerja membantu keluarga untuk menghasilkan pendapatan. Kecamatan yang terbanyak untuk kasus ini adalah Kecamatan Mapanget, Tikala dan Wanea. Sedangkan penduduk yang masih tetap produktif sampai pada usia lanjut tampak dominan di Kecamatan Tuminting dan Singkil. Pemerintah daerah harus memberikan perhatian khusus bagi anak-anak di bawah umur yang sudah harus ikut membebani keluarga dalam meningkatkan perekonomian. 


\section{Gambar 4. Jumlah Individu Perempuan Yang Tidak Bekerja} Menurut Kecamatan di Kota Manado Tahun 2015

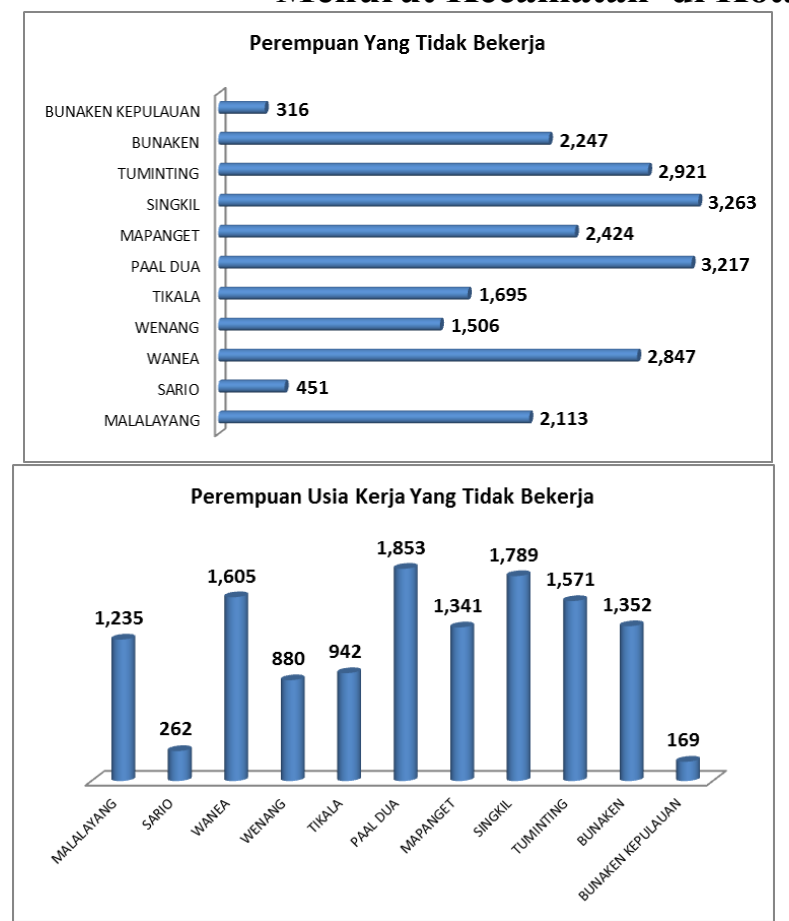

Sumber : BDT, Diolah 2016

Secara umum tampak bahwa perempuan yang tidak bekerja banyak terdapat di Kecamatan Singkil dan Paal Dua. Sehingga penting peningkatan produktivitas tenaga kerja perempuan di kedua kecamatan ini. Perempuan Usia kerja yang tidak bekerja banyak terdapat di Dari jenis pekerjaan yang paling dominan adalah bekerja pada jenis pekerjaan bangunan dan jasa konstruksi serta jasa-jasa lainnya yang terdiri atas jasa kemasyarakatan, jasa pendidikan dan kesehatan, jasa pemerintahan dan perorangan.

Model yang dibangun menunjukkan bahwa Tingkat Pengangguran Terbuka (TPT) diduga dipengaruhi oleh usia angkatan kerja perempuan (X1); Sektor Pertanian (X2); Sektor Jasa (X3); Sektor Industri Kecil (X4) dan Sektor Perdagangan Hotel dan Restoran (X5). Hasil run data menunjukkan bahwa :

$$
\begin{aligned}
& \mathrm{TPT}=0,0321+0,035 \mathrm{X} 1 *+0,076 \mathrm{X} 2-0,215 \mathrm{X} 3 *-0,342 \mathrm{X} 4-0,642 \times 5^{*}+ \\
& \varepsilon
\end{aligned}
$$

Ket : *) signifikan

Tampak bahwa tingkat pengangguran terbuka perempuan di Kota Manado secara signifikan dipengaruhi oleh usia angkatan kerja perempuan, sektor jasa, dan sektor PHR. Dimana hubungan variabel bebas terhadap variabel terikat menunjukkan bahwa usia angkatan kerja perempuan memiiki hubungan positif artinya bahwa peningkatan jumlah angkatan kerja perempuan mendorong meningkatnya TPT perempuan di Kota Manado. Sedangkan Sektor jasa dan PHR memiliki hubungan negatif artinya daya serap tenaga kerja di kedua sektor ini secara signifikan menurunkan TPT permpuan di Kota Manado. 
Dilihat dari besarnya pengaruh hasil run data menunjukkan bahwa yang paling berpengaruh terhadap naik-turunnya TPT perempuan di Kota Manado adalah sektor PHR, diikuti oleh sektor jasa dan usia angkatan kerja perempuan. Dimana hubungan antara variabel menunjukkan besarnya koefisien korelasi adalah 0,832 artinya terdapat hubungan variabel bebas dengan variabel terikat sebesar 83,2 persen. Dengan besarnya variasi perubahan TPT dipengaruhi oleh variasi perubahan jumlah usia angkatan kerja perempuan, sektor jasa dan sektor PHR sebesar 69,2 persen. Pemerintah Kota Manado memiliki 8 program unggulan diantaranya pelatihan dan sertifikasi tenaga kerja.

\section{KESIMPULAN DAN REKOMENDASI}

Masalah pengangguran di Kota Manado memberika dampak bagi peningkatan pertumbuhan ekonomi daerah terutama dalam rangka mendukung pembangunan manusia secara menyeluruh. Tampak bahwa karakteristik pengangguran di Kota Manado terutama disebabkan oleh masyarakat masih memilih-milih pekerjaan, karena tingkat pendidikan yang dimilikinya. Meningkatnya penduduk usia kerja perempuan yang ingin bekerja sehingga meningkatkan tingkat pengangguran terbuka di Kota Manado. Tingginya turn over pada daerah perkotaan terutama ibukota provinsi, yang menyebabkan waktu tunggu kerja pada beberapa jenis pekerjaan menjadi meningkat.

Pentingnya Koordinasi antara Kabupaten/Kota yang menangani permasalahan Ketenagakerjaan lebih ditingkatkan. Kebijakan mengoptimalkan job fair untuk mengurangi asymetric information, meningkatkan wirausahawan baru baik melalui jalur pendidikan formal maupun non formal. Rekruitmen dengan sistem semacam "ikatan kerja" sehingga ada jaminan keberlanjutan kerja dan peningkatan profesionalisme kerja. Menumbuhkan wiraswasta perempuan yang memilih berbisnis atau bekerja di sektor swasta. Pelatihan khusus untuk peningkatan ketrampilan yang mempersiapkan perempuan menjadi pekerja swasta yang siap masuk pasar kerja. Bantuan fasilitas dan beasiswa bagi SMK dan akademi yang berkaitan dengan sektor PHR maupun jasa lainnya.

\section{DAFTAR PUSTAKA}

Badan Pusat Statistik, 2010, "Pedoman Pencacahan Survei Angkatan Kerja Nasional (Sakernas) 2010”, Badan Pusat Statistik. Jakarta.

Badan Pusat Statistik, 2011, "Kondisi Angkatan Kerja Indonesia", Badan Pusat Statistik. Jakarta.

Badan Pusat Statistik Provinsi Sulawesi Utara, 2012, "Kondisi Angkatan Kerja Provinsi Sulawesi Utara”, BPS Provinsi Sulawesi Utara. Manado.

Badan Pusat Statistik Provinsi Sulawesi Utara, 2011, "Berita Resmi Statistik Ketenagakerjaan Edisi 7 November 2011”, BPS Provinsi Sulawesi Utara. Manado.

Badan Pusat Statistik Provinsi Sulawesi Utara, 2012, "Berita Resmi Statistik Ketenagakerjaan Edisi 5 November 2012”, BPS Provinsi Sulawesi Utara. Manado 
Baker, D., A. Glyn, D. Howell and J. Schmitt, 2003, “Labor Market Institutions and Unemployment: a Critical Assessment of The Cross-country Evidence”, Harvard University, Minda de Gunzburg Center for European Studies, Working Paper, No. 98.

Conceicao P, P. Ferreira and J.K. Galbraith, 1999, “Inequality and Unemployment in Europe: The American Cure", New Left Review, no. 237, SeptemberOctober, pp. 28-51.

Elsby, Michael, Bart Hobijn, and Ayşegül Şahin, 2009, “Unemployment Dynamics in the OECD”, NBER Working Paper no. 14617, December.

Galbraith J.K, and Garcilazo E, 2004, “Unemployment, Inequality and The Policy of Europe: 1984-2000”, BNL Quarterly Review, no. 228, March.

Ham J.C, Svejnar J, and Terrell K, 2001, “Women's Unemployment During The Transition: Evidence From Czech and Slovak Micro Data”.

Harris, J.R. and M.P. Todaro, 1970, “Migration, Unemployment and Development: a Twosector Analysis”, The American Economic Review, vol. 60, issue 1, pp. 126-42.

Keynes, J.M, 1936, "The General Theory of Employment, Interest and Money", Macmillan, London.

Kuznets, S, 1955, “Economic Growth And Income Inequality”, American Economic Review, Vol. 65, no. 1, pp. 1-28.

Planning Commission, Goverment of India, 2002, “ A Study of Unemployment Among Female Graduates In Pune City”, Indian Institute of Education, Vol. 128, No.2, Kothrud,Pune.

Pruthi, Raj Kumar, Rameshwari Devi, Pruthi, Romila, 2001, “Education, Employment and Empowerment of Women”, Mangal Deep Publications, Jaipur.

Rahardja Pratama dan Mandala Manurung, 2000, “ Teori Ekonomi Makro”, Edisi 2, LPFE-UI, Jakarta.

Sukirno Sadono, 2007, “ Makro Ekonomi Modern Perkembangan Pemikiran dari Klasik hingga Keynesian Baru “, PT Raja Grafindo Persada, Jakarta.

Sahin A, Song J and Hobijn B, 2010, “ The Unemployment Gender Gap During The 2007 Recession”, Current Issue in Economics and Finance, Vol 16, No. 2 February. 
Shimer, Robert, 2005, “The Cyclical Behavior of Equilibrium Unemployment and Vacancie.”, American Economic Review 95, no. 1 (March) pp. 25-49.

Simanjuntak Payaman, 2001, “Pengantar Ekonomi Sumber Daya Manusia”, Edisi 2, LPFE-UI, Jakarta

Swasono, 2000, “ Metode Perencanaan Tenaga Kerja Tingkat Nasional dan Regional “, BPFE-UGM, Yogyakarta.

Varshney, H.K., 1990, “Education and Employment Planning for Young Women”, The Indian Journal of Labour Economic, Vol.33, No.3, July-Sept.

Visaria, Pravin, 1997, "Women in The Indian Working Force: Trends and Differentials", Artha Vijnana, 39(1): 1-136.

---------, 1998, “Unemployment Among Youth in India: Level, Nature and Policy Implications”, Employment and Training Papers, No. 36, International Labour Office Geneva, ISBN 92-2-111417-1, ISSN 1020 - 5322 